\title{
The Impact of Psychological Factors on Consumers Trust in Adoption of M-Commerce
}

\author{
Muhammad Suhail Sharif ${ }^{1}$, Bingjia Shao ${ }^{2}$, Feng Xiao ${ }^{2} \&$ Muhammad Kashif Saif $^{2}$ \\ ${ }^{1}$ Department of Economy and Business Administration, Chongqing University, China \\ ${ }^{2}$ College of Economics and Business Administration, Chongqing University, China \\ Correspondence: Bingjia Shao, College of Economics and Business Administration, Chongqing University, \\ Chongqing, 400030, P. R. China. E-mail: shaobj@126.com
}

Received: February 22, 2014

Accepted: March 20, 2014

Online Published: April 24, 2014

doi: 10.5539/ibr.v7n5p148

URL: http://dx.doi.org/10.5539/ibr.v7n5p148

\begin{abstract}
Consumer trust plays an important role in adoption of any technology. This study targets to determine the psychological elements that affect the consumers' trust in adoption of m-commerce. Many researchers investigate the said factors in e-commerce and online retailing, m-commerce in broad sense resembles with e-commerce but since mobile device is smaller in size so the psychological factor specifically consumer trust becomes more critical. This study focusses on partition of psychological factors that revolve around three main categories, i.e., personality-based, internal perception-based and external perception-based factors. Data is collected from 222 university students having temptation and experience of m-commerce. Subsequently, regression analysis is made in order to test the hypothesis. The research carried out on the element of psychological factors of consumers in $\mathrm{m}$-commerce, reveals that among the said categories while adopting m-commerce, internal perception-based factors are the key determinants of consumer trust.
\end{abstract}

Keywords: m-commerce, consumers trust, psychological factors, adoption of m-commerce

\section{Introduction}

The growth of mobile networks and wireless devices start from 1990s till to date. Businesses, academics, and even individuals start focusing on this new technology, they shifted from offline mode to online mode (Ngai, 2007). With the advent of this new technology, mostly people used their personal computers and laptop on wired network but after that to get the advantage of ubiquity irrespective of time and place constraints, many businessman and individuals moved from wired devices to wireless devices like mobile phone and hand held devices (PDA), referred as mobile commerce. In terms of business, mobile commerce is defined as all the transactions conducted via hand held devices, e.g., personal digital assistant and other mobile phone devices using the wireless communication network (Alain, 2013). It can also be defined as subset of e-commerce in which transaction of goods and services via wireless hand held devices (Coursaris et al., 2002). The total number of mobile subscriber in 2010 was near about 5 billion worldwide, and out of them 1.2 billion subscriber used mobile web (Alain et al., 2012). With the usage of smart phones, subscribers can access internet and search information with less efforts because data can be entered easily due to fixed keyboard. It makes data entry easier as indicated by recent survey which exhibits that the travel search via mobile devices such as smart phones increased in $1200 \%$ though hotel searches on google map grew up 3000\% in 2011 in particular (Torres, 2011). According to Asghar et al. $\mathrm{m}$-commerce is applied in banking sector, location based services, health, tracking and dispatching inventory, education, mobile advertising, entertainment and mobile ticketing etc.

M-commerce couldn't not reach to the maturity stage as reflected by many studies since failed to attract the potential consumers (Alhinai et al., 2010). Due to the aforementioned fact, it is essential to analyze and comprehend the factors that influence the consumer decision to adopt the m-commerce. The technology acceptance model (TAM) has been used by a number of researchers, to describe the adoption of new technology by an individual because of its usefulness and ease of use (Adams, 1992; Agarwal, 2000). Some other theories also provided explanation about technology adoption such as theory of planned behavior (Ajzen, 1991) and diffusion of innovation theory (Rogers, 1995). Mobile commerce has different characteristics from other technologies that were studied in the past, it is important to extend the previous models to explain the m-commerce adoption (Wei et al., 2009). Pedersson (2002) stated that there are three entities in m-commerce: technology, mobile network and 
consumers. In the past studies, consumer trust is treated as an independent variable in the adoption of m-commerce.

Trust is a complex construct because previous researchers have defined it from different perspective and disciplines and there is not a specific definition of trust. Trust is related to the psychology of consumers emotionally and logically. Emotionally, it is where one exposes the vulnerabilities to people or entity with the belief that they will not get advantage of its openness. Logically, it is where one assessed the probabilistic ratio of benefits and losses, calculating estimated utility based on hard performance data, and concluded that the person or entity in question will act as a predictable way. According to Rousseau, (1998) trust is defined as "a psychological state comprising the intention to accept vulnerability based upon positive expectations of the intentions or behavior of another". Trust becomes more critical in online processing rather than in an offline mode. In online processing the consumers and sellers have no direct physical contact and the consumer cannot be seen or touched the product. There is no doubt that consumers' trust is very important in adoption of any new technology, such as m-commerce. We consider trust as an intermediate variable in the adoption of m-commerce. In this study we examined that how psychological factors affect the consumers' trust in m-commerce adoption. In our study, we categories these psychological factors into three groups: personality-based factors, internal perception-based factors and external perception-based factors, and measure the effect of these factors on consumers' trust in adoption of m-commerce.

The remaining portion of this article is organized as follows: Section 2 describes the research model and hypotheses development. Section 3 describes the research methodology including data collection and data analysis. Section 4 describes hypothesis testing and results. Finally, conclusions discuss in section 5.

\section{Research Model and Hypotheses Development}

\subsection{Psychological Factors and Consumers' Trust in M-Commerce}

Trust is related the psychology of the consumers and different researcher defined it in different way. Trust is one party's psychological expectations that another party will not engage in opportunistic behaviors (Mayer, 1995). It is also defined the inclination of a party to be vulnerable to the action of another party. We have grouped the psychological factors into three categories which affect the consumers' trust in adoption of mobile commerce.

1) Personality-based factors;

2) Internal perception-based factors;

3) External perception-based factors.

From the previous literature, a conceptual model based on the above three factors is depicted in Figure 1. This shows the hypothesized effects of these factors on consumers' trust in adoption of m-commerce.

\subsubsection{Personality-Based Factors and Trust in M-Commerce}

According to Dibb et al. (1994) the personality contains of "all the internal traits and behaviors that make a person unique". To examine the impact of personality-based factors on consumers' trust in adoption of m-commerce, we used the Big Five personality framework presented by (McCrae \& Costa, 1987). In the field of psychology, to understand the individual's personality is not so simple but the Big Five model is widely accepted personality taxonomy that consists of five factors: Extraversion, agreeableness, open to experience, conscientiousness and neuroticism. All the stated factors are defined in the forthcoming section; in previous literature many researchers have explained these factors in different ways (Angenent, 1998; Gleitman, 1995; Olson, 1998; Rita et al., 2004).

Extraversion can be defined people focused on outside world. Extraverts feel happy and comfortable among other people's company. These people are very careless, social able and usually adapt the change quickly. It can also be stated that extraverts' people trust on other people and entity easily.

Agreeableness can be defined as the people who have positive beliefs toward others and give value to their suggestions. These types of people perceived that others will give respect to their emotions and will not misguide them. On the other hand people who score low on agreeableness give less importance to other's ideas and suggestions. Therefore, people high in agreeableness are trust on others easily.

Openness to experience can be defined as the people who are open minded. Open minded people usually make liberal decisions. The people who are low in openness to experience are very conservative and careful in decision making. Open minded people adapt the new technology just for experience, so we can say that these people can trust easily.

Conscientiousness can be defined as the people who are very careful in decision making; they always make the plan and then follow them. More conscientious people usually associated with trust negatively, they are not quick 
adapter of changes.

Neuroticism is defined as the people who are emotionally instable, pessimism and have not confident in practical life. These kinds of people always think there is going something wrong with them. They are very pessimistic, and they are not quick to adapt the change. In addition, they tend to be more serious and cautious in making decisions. According to the aforementioned definition, our hypotheses are as:

H1: Personality-based factors such as extraversion, agreeableness and openness to experience will have a positive influence on consumers' trust in adoption of m-commerce.

H2: Personality-based factors such as conscientiousness and neuroticism will have a negative influence on consumers' trust in adoption of m-commerce.

\subsubsection{Internal Perception-Based Factors and Consumer Trust in M-Commerce}

Internal perception means the consumers' belief about the technology internally, that how much it's easy and useful. According to Liyi et al. (2012) technology acceptance model (TAM) pays attention on consumers' internal perceptions. Davis (1989) proposed the (TAM) technology acceptance model, perceived usefulness and perceived ease of use are two constructs of this model. In our study, we measure the effect of these two variables on consumers' trust in the adoption of m-commerce.

\section{Perceived Usefulness (PU)}

Perceived usefulness is defined as "the degree to which a person believes that using a particular system would enhance his or her job performance" (Davis, 1989). The effect of perceived usefulness on intention to adopt m-commerce has been validated in many existing studies (Luarn \& Lin, 2005). Several researchers have argued that perceived usefulness will have a positive effect on consumers' trust in e-vendor and in e-commerce (Chau, $\mathrm{Hu}$, Lee, \& Au, 2007; Pavlou, 2003; Tang \& Chi, 2005). Wong et al. (2005) suggested that the usage of m-commerce is strongly driven by the usefulness of mobile service, which includes ubiquity, personalization, localization timeliness and network stability. Logically, as the technology more useful, it will positively influence consumer trust to adopt. So we can hypothesize that:

H3: PU will have a positive influence on consumers' trust in adoption of m-commerce.

\section{Perceived Ease of Use (PEOU)}

It is generally accepted that perceived ease of use has a significant and positive relationship with user intention to adopt new technology. Perceived ease of use is defined as "the degree to which a person believes that using a particular system would be free of effort" (Davis, 1989). Xu et al. (2004) highlighted the significant effect of perceived ease of use of the website on online trust. Several researchers have argued that perceived ease of use will have a positive effect on consumers' trust in e-vendor and in e-commerce (Chau, Hu, Lee, \& Au, 2007; Pavlou, 2003; Tang \& Chi, 2005). As the usage of m-commerce will be easy and free of efforts consequently consumer's trust in adoption of m-commerce will positively influenced. This research hypothesizes that:

H4: PEOU will have a positive influence on consumers' trust in adoption of m-commerce.

\subsubsection{External Perception-Based Factors and Trust in M-Commerce}

External perception-based factors mean those factors which affect the consumer believes externally about the technology. According to Liyi et al. (2012) theory of planned behavior (TPB) pays attention on users' external perceptions about technology. Social influence, perceived risk and cost are external factors that affect consumers' trust in the adoption of mobile commerce.

\section{Perceived Risk (Risk)}

Perceived risk can be described as a consumer's belief about the possible undefined negative outcomes from the online transaction (Kim et al., 2008). Hansson (2004) stated that risk as a possible but not certain future harm, or the probability of such a harm, or the expected disutility of such a harm. Trust is defined as the willingness, in expectation of beneficial outcome while risk is defined potential of loss (an undesirable outcome) resulting from a given action or activity. So we can say that trust and risk are negatively associated with each other. This research hypothesizes that:

H5: Perceived risk will have a negative influence on consumers' trust in adoption of m-commerce.

\section{Social Influence (SI)}

Social influence occurs when one's emotion, opinion or behaviors are affected by others. Wei et al. (2009) argues that besides family and friends, mass media also influence the consumer's decisions to adopt m-commerce such as 
television, radio, magazines, newspapers and the internet are potential media capable of influencing the consumer's decisions to adopt m-commerce. According to Alfhian et al., there is a positive relationship between social influence and trust in the internet. Based on the above studies, this research hypothesizes that:

H6: Social influence will have a positive influence on consumers' trust in adoption of m-commerce.

\section{Cost}

In previous research (Agarwal et al., 2007) stated that price is one of the main barriers for user to adopt technology. Wei et al. stated that cost is one factor that can slow the development of m-commerce. In previous literature we did not find the relationship between cost and trust in adoption of $\mathrm{m}$-commerce. In $\mathrm{m}$-commerce there are three types of cost involved: technology, mobile network and transaction cost. So logically, economic point of view cost negatively influenced the consumer trust in adoption of m-commerce. According to previous researches cost has also direct negative impact on adoption of m-commerce. This research hypothesizes that:

H7: Cost will have a negative influence on consumers' trust in adoption of m-commerce.

H8: Cost will have a negative influence on adoption of m-commerce.

Trust

Trust plays significant role in business transaction, but in case of online transaction it becomes more serious like in e-commerce or m-commerce. Trust is a key factor which affects consumer decisions to adopt technologies such as e-commerce (Alain, 2013). Gefen et al. (2003) argues that trust is able to influence consumer's intentions to buy online. They also stated that trust is developed by the belief that an e-vendor will not achieved by dishonest behavior, having security mechanisms built in website, having a typical interface and ease to use. According to Rousseau trust is defined as "a psychological state comprising the intention to accept vulnerability based upon positive expectations of the intentions or behavior of another". This research hypothesizes that:

H9: Trust will have a positive influence on adoption of m-commerce.

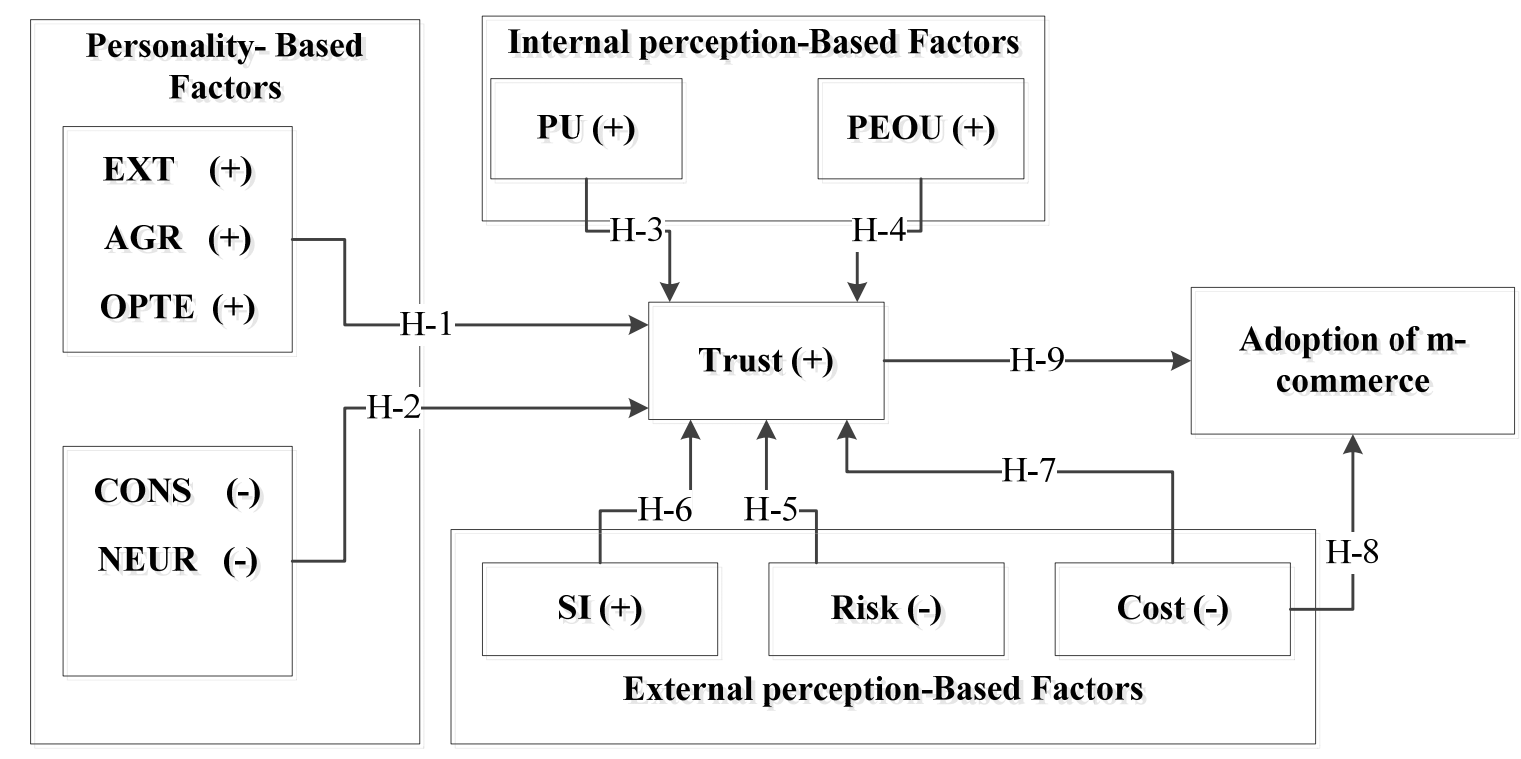

Figure 1. Conceptual model

\section{Methodology}

\subsection{Sampling and Data Collection}

In order to test the hypotheses, a survey questionnaire was developed. The survey was translated into Chinese language by a language instructor for better understanding of respondents. The survey questionnaire was pre-tested with twenty five students who are the user of m-commerce, and two university professors, whose main research area are in the field of e-commerce and e-business. We believe that students are a very good target group for a research study in the field of m-commerce, because they can be the frequent users of mobile devices with respect to buying and other online activities. The questionnaires were distributed in various departments in 
different universities in China in person and via email. A total of 222 surveys were collected, consisting of 116 male $52.3 \%$ and 106 female $47.7 \%$. Table 1 summarizes the demographic profile of the participants.

Table 1. Demographic profile

\begin{tabular}{lcc}
\hline Demographic profile & Number & Percentage \\
\hline Gender & 116 & 52.3 \\
Male & 106 & 47.7 \\
Female & & \\
Age of respondents & 2 & 0.9 \\
$15-18$ & 156 & 70.3 \\
$19-22$ & 42 & 18.9 \\
$23-26$ & 16 & 7.2 \\
$27-30$ & 6 & 2.7 \\
Above 30 & & \\
Education level & 7 & 3.2 \\
Secondary school & 27 & 12.2 \\
Higher secondary school & 94 & 42.3 \\
Bachelor degree & 73 & 32.9 \\
Master degree & 21 & 9.5 \\
PhD or above & & \\
Purchase experience & 208 & 93.7 \\
Yes & 14 & 6.3 \\
No & & \\
\hline
\end{tabular}

\subsection{Variable Measurement}

In this research, the independent and dependent variables used are adapted from previous literature Alain et al. (2012), Kim, Chan and Gupta (2007), Rita (2004) and Mertinez and John (1998). 42 items were used to measure the 11 independent variables in this study and 4 questions were used to measure the dependent variable. The demographic variables are measured in term of gender, age, and education level and $\mathrm{m}$-commerce experience. The independent variables and dependent variables are measured on a seven-point Likert Scale ranging from 1 (strongly disagree) to 7 (strongly agree).

\subsection{Scale Reliability}

The reliability of the constructs was tested through Cronbach's alpha. The reliability coefficients $(\alpha)$ of the variables are shown in Table 2. According to Rita et al. (2004) an alpha of 0.50 or higher indicates a sufficient level of internal reliability. The reliability coefficients $(\alpha)$ of all independent variables are above 0.60 that confirming the items used to measure the constructs are reliable. As we can see from Table 2 majority of constructs lie between 0.60 to 0.80 which shows that coefficients $(\alpha)$ of all independent variables are reliable.

\section{Hypotheses Testing and Results}

Regression analysis was used to test the hypotheses in this study. In first step measured the effect of all independent variable on consumers' trust in which the f-ratio of regression is 8.68 and statistically significant $(\mathrm{P}<0.01)$. And in second step measured the effect of trust and cost on the adoption of m-commerce in which f-ratio is 26.92 statistically significant $(\mathrm{P}<0.01)$. 
Table 2. Reliability analysis

\begin{tabular}{lc}
\hline \multicolumn{1}{c}{ Constructs } & Cronbach's alpha \\
\hline Extraversion (EXT) & 0.79 \\
Agreeableness (AGR) & 0.77 \\
Open-to-experience (OPTE) & 0.66 \\
Conscientiousness (CONS) & 0.83 \\
Neuroticism (NEUR) & 0.67 \\
Trust & 0.67 \\
Perceived risk (Risk) & 0.66 \\
Perceived cost (Cost) & 0.71 \\
Social influence (SI) & 0.60 \\
Perceived usefulness (PU) & 0.76 \\
Perceived ease of use (PEOU) & 0.63 \\
\hline
\end{tabular}

Table 3. Result of hypothesis

\begin{tabular}{lccc}
\hline Constructs & Standard beta & Standard error & Significance \\
\hline Constant & & .496 & 0.040 \\
Extraversion & 0.071 & .070 & 0.360 \\
Agreeableness & 0.280 & .075 & $0.000^{*}$ \\
Open-to-experience & 0.015 & .091 & 0.870 \\
Conscientiousness & -0.103 & .077 & 0.211 \\
Neuroticism & -0.004 & .055 & 0.948 \\
Perceived risk & -0.075 & .057 & 0.244 \\
Social Influence & 0.008 & .054 & 0.906 \\
Perceived usefulness & 0.296 & .072 & $0.000^{*}$ \\
Perceived ease of use & 0.166 & .065 & $0.017^{* *}$ \\
Cost & -0.017 & .057 & 0.764 \\
\hline
\end{tabular}

Note. Dependent Variable: trust; $*$ Significant at $\alpha<0.01 ; * *$ Significant at $\alpha<0.05 ; * * *$ Significant at $\alpha<0.1$.

Table 4. Result of hypothesis

\begin{tabular}{lccc}
\hline Constructs & Standard beta & Standard error & significance \\
\hline (Constant) & & .380 & $.000^{*}$ \\
Trust & .434 & .065 & $.000^{*}$ \\
Cost & .100 & .060 & .100 \\
\hline
\end{tabular}

Note. Dependent Variable: Adoption.

From the study, the hypothesis derived is that extraversion (EXT), agreeableness (AGR) and openness to experience (OPTE) positively influenced consumers' trust in adoption of $\mathrm{m}$-commerce. Although all the variables have positive effect but only agreeableness $(\beta=0.280$ and $p<0.01)$ have significant impact on consumer trust in adoption of m-commerce. So H1 is partially supported. In $\mathrm{H} 2$ conscientiousness (CONS) and neuroticism (NEUR) have negative effect but not significant, so $\mathrm{H} 2$ is rejected. In $\mathrm{H} 3$ perceived usefulness (PU) $(\beta=0.296$ and $p<0.01)$ and $\mathrm{H} 4$ perceived ease of use $(\mathrm{PEOU})(\beta=0.166$ and $\mathrm{p}<0.05)$ both are supported. All the external perception-based factors perceived risk $\mathrm{H} 5$, social influenced $\mathrm{H} 6$ and cost $\mathrm{H} 7$ are not supported. In $\mathrm{H} 8$ cost has not significant effect on adoption of m-commerce, so it is also rejected. Therefore trust $\mathrm{H} 9$ has positive, significant effect on adoption of 
m-commerce $(\beta=0.434$ and $\mathrm{p}<0.01)$ so it is supported.

\section{Conclusion}

Personality-based, internal perception-based and external perception-based factors are hypothesized to observe the effect of these factors on consumers' trust in the adoption of m-commerce. A comprehensive survey is carried out with the aim to analyze the factors that predict consumer trust in adoption of m-commerce. It has been found that internal perception-based factors are main determinants of consumers' trust in adoption of m-commerce. Perceived usefulness (PU) and perceived ease of use (PEOU) are used as perception-based factors. The technology acceptance model (TAM) of Davis revolves around the factor that perceived usefulness and perceived ease of use have positive influence on adoption of technology while our study proved it that from psychological aspect that the same two factors also have positive influence on consumers' trust in adoption of m-commerce. In personality-based factors we have examined five factors. Among them, extraversion, agreeableness and open to experience have positive impact on consumers' trust in adoption of m-commerce while merely agreeableness could achieve the significant level. Conscientiousness and neuroticism, the two remaining personality-based factors have negative effect on consumers' trust in adoption of m-commerce and also couldn't reach the significant level. Thus, it is deduced that personality-based factors are not so vital in determining the trust while adopting m-commerce. Likewise, the external perception-based factors such as social influence, perceived risk and perceived cost did not prove any impact on consumer trust in adoption of m-commerce. Consequently, our research study concludes that with the ease of the technology along with its usefulness, consumer trust gets enhance remarkably.

\section{Acknowledgement}

Project Supported by National Natural Science Foundation of China (NO. 71002070) Project Supported by the Fundamental Research Funds for the Central Universities (No. CQDXWL-2012-170) and Science and Technology Innovation Fund for individual Graduate Students of Chongqing University (CDJXS12020007).

\section{References}

Alain, Y. L. C. (2013). Predicting m-commerce adoption determinants: A neural network approach. Expert System with Application, 40(2), 523-530. http://dx.doi.org/10.1016/j.eswa.2012.07.068

Alain, Y. L. C., Felix, T. S. C., \& Keng, B. O. (2012). Predicting consumer decisions to adopt mobile commerce: Cross country empirical examination between China and Malaysia. Decision Support System, 53(1), 34-43. http://dx.doi.org/10.1016/j.dss.2011.12.001

Asghar, A. J., Alireza, M., \& Amin, A. (2011). Mobile commerce beyond electronic commerce: Issue and challenges. Asian Journal of Business and Management Science, 1(2), 119-129. http://www.ajbms.org/articlepdf/ajbms_2011_1219.pdf

Alhinai, Y. S, Kurnia, S., \& Smith, S. P. (2010). The adoption of mobile commerce services by individuals, (Conference proceeding).

Adams, D. A., Nelson, R. R., \& Todd, P. A. (1992). Perceived usefulness, ease of use, and usage of information technology: a replication. MIS Quarterly, 16(2), 227-247. http://dx.doi.org/10.2307/249577

Agarwal, R., \& Karahanna, E. (2000). Time flies when you are having fun: cognitive absorption and beliefs about information technology usage. MIS Quarterly, 24(4), 665-694. http://dx.doi.org/10.2307/3250951

Ajzen, I. (1991). The theory of planned behavior. Organizational Behavior and Human Decision Process, 52(2), 179-211. http://dx.doi.org/10.1016/0749-5978(91)90020-T

Alfhian, J. C., Wafa, S. A., Wafa, S. K., \& Ooi, A. Y. (2009). The effect of internet trust and social influence towards willingness to purchase online in Labuan, Malaysia. International Business Research, 2(2), 72-81.

Coursaris, C., \& Hassanein, K. (2002). Understanding m-commerce quarterly. Journal of Electronic Commerce, $3(3), 247-271$.

Chau, P. Y. K., Hu, P. J. H., Lee, B. L. P., \& Au, A. K. K. (2007). Examining customers' trust in online vendors and dropouts: An empirical study. Electronic Commerce Research and Applications, 6(2), 171-182. http://dx.doi.org/10.1016/j.elerap.2006.11.008

Dibb, S. L., Simkin, W. M., \& Pride, O. C. (1994). Ferrell, Marketing concepts and Strategies. Boston, MA: Houghton Mifflin Company.

Gefen, D., Karahanna, E., \& Straub, D. W. (2003). Trust and TAM in online shopping: An integrated model. MIS Quarterly, 27, 51-90. 
Gleitman, H. (1995). Psychology. New York, NY: W. W. Norton \& company, Inc. Retrieved from http://www.qualities-of-a-leader.com/personal-mbti-type-analysis/

Kim, D. J., Ferrin, D. L., \& Rao, H. R. (2008). A trust-based consumer decision making model in electronic commerce: the role of trust, perceived risk, and their antecedents. Decision Support System, 44(2), 544-564. http://dx.doi.org/10.1016/j.dss.2007.07.001

Li, Y. Z., Jing, Z., \& Qi, H. L. (2012). A meta-analysis of mobile commerce adoption and the moderating effect of culture. Computer in Human Behavior, 28, 1902-1911. http://dx.doi.org/10.1016/j.chb.2012.05.008

Mayer, R. C., Davis, J. H., \& Schoorman, F. D. (1995). An integrative model of organizational trust. Acad Manag Rev, 20(3), 709-734.

McCrae, R. R., \& Costa, P. T. (1987). Validation of the five-factor model of personality across instruments and observers. Journal of Personality \& Social Psychology, 52, 81-90. http://dx.doi.org/10.1037/0022-3514.52.1.81

Ngai, E. W. T., \& Gunasekaram, A. (2007). A review for mobile commerce research and applications. Decision Support Systems, 43(1), 3-15. http://dx.doi.org/10.1016/j.dss.2005.05.003

Olson, B. D., \& Suls, J. (1998). Self-other and ideal judgments of risk and caution as a function of the five factor model of personality. Personality and Individual Differences, 28(1), 425-436. http://dx.doi.org/10.1016/S0191-8869(99)00105-1

Pedersson, P. E., \& Heinonen, K. (2002). Acceptance of mobile services: Insights from the Swedish market for mobile telephony. SSE/EFI working paper series in business administration 16.

Pavlou, P. A. (2003). Consumer Acceptance of Electronic Commerce-Integrating Trust and Risk with the Technology Acceptance Model. International Journal of Electronic Commerce, 73, 69-103.

Rogers, E. M. (1995). Diffusion of Innovation. New York: Free Press.

Rita, W., \& Henriette, L. (2004). Psychological antecedents of institution-based consumer trust in e-retailing. Information \& Management, 42, 159-177. http://dx.doi.org/10.1016/j.im.2003.12.009

Rousseau, D., Sitkin, S., Burt, R., \& Cammerer, C. (1998). Not so different after all: a cross-discipline view of trust. Acad manag Rev, 23(3), 393-404. http://dx.doi.org/10.5465/AMR.1998.926617

Torres, R. (2011). Hospitality marketing goes digital. Lodging Hospitality. Retrieved from http://honline.com/operations/salesmarketing/hospitality-marketing_goes_digital_0318/

Tang, T. W., \& Chi, W. H. (2005). The Role of Trust in Customer Online Shopping Behavior: Perspective of Technology Acceptance Model. Paper presented at the Proceedings of NAACSOS Conference 2005 Indiana, USA.

Wei, T. T., Marthandan, G., Chong, A. Y. L., Ooi, K. B., \& Arumugam, S. (2009). What drives Malaysian m-commerce adoption? An Empirical Analysis. Industrial Management \& Data Systems, 109, 370-388. http://dx.doi.org/10.1108/02635570910939399

\section{Copyrights}

Copyright for this article is retained by the author(s), with first publication rights granted to the journal.

This is an open-access article distributed under the terms and conditions of the Creative Commons Attribution license (http://creativecommons.org/licenses/by/3.0/). 